\title{
Pengaruh Inhibitor Ekstrak Daun Jambu Biji (Psidium guajava) Terhadap Laju Korosi Selongsong Amunisi Kaliber 7.62 mm Dalam Media $\mathrm{CH}_{3} \mathrm{COOH}$ dan $\mathrm{HCl}$
}

\author{
(Effect of Inhibitor Extract of Guava Leaf (Psidium guajava) on \\ Corrosion Rate of Ammunition Case Caliber $7.62 \mathrm{~mm}$ in \\ $\mathrm{CH}_{3} \mathrm{COOH}$ and $\mathrm{HCl}$ Media)
}

\author{
Andini Dyah Anugrahita ${ }^{*}$, Ardian Infantono ${ }^{2}$, M. Sakti La Ore ${ }^{3}$ \\ 1,2,3 Program Studi Teknik Aeronautika Pertahanan, Akademi Angkatan Udara Yogyakarta, Indonesia \\ E-mail: andinidyah117@gmail.com,ardian.infantono@aau.ac.id,laoresakti@gmail.com
}

\begin{abstract}
Corrosion can occur in any metal, including brass metal as raw material for making ammunition casing. One way to inhibit corrosion is to use corrosion inhibitors which can be made using organic materials. Guava leaf (Psidium guajava) contain tannin compounds as corrosion inhibitors. In this study, the brass used was the casing of the MU-2TJ ammunition caliber $7.62 \mathrm{~mm}$ produced by PT. Pindad in 1992 and 1994. Corrosion rate was calculated by the method weight loss. Inhibitor preparation of guava leaf extract was carried out by maceration method, where 10 grams of dried guava leaf were dissolved in $100 \mathrm{~mL}$ water-ethanol solvent with various volume ratios of water : ethanol 7:3, 6:4, and 5:5, respectively. Brass with inhibitor and without inhibitor was immersed for 15 days or 360 hours in $\mathrm{HCl}$ and $\mathrm{CH}_{3} \mathrm{COOH}$ solution media. . The results showed that in $\mathrm{CH}_{3} \mathrm{COOH}$ media, the largest inhibitor efficiency was $42.12 \%$ by using guava leaf extract inhibitor with a ratio of volume water : ethanol 6:4 in $\mathrm{CH}_{3} \mathrm{COOH} 0.1 \mathrm{M}$ solution, where the corrosion rate of brass without inhibitors is $4.34 \times 10^{-6}$ mpy and the corrosion rate of brass with inhibitors is $2.51 \times 10^{-6} \mathrm{mpy}$. In $\mathrm{HCl}$ media, the largest inhibitor efficiency was $7.52 \%$ by using guava leaf extract inhibitor with a ratio of volume water : ethanol 5:5 in $\mathrm{HCl} 0.05 \mathrm{M}$ solution, where the corrosion rate of brass without inhibitors is $4.81 \times 10^{-6}$ mpy and the corrosion rate of brass with inhibitors is $4,45 \times 10^{-6}$ mpy.
\end{abstract}

Keywords- Ammunition, Brass, Corrosion, Inhibitor, Corrosion Rate

Abstrak-Korosi dapat terjadi pada setiap logam, termasuk logam kuningan sebagai bahan baku pembuatan selongsong amunisi. Salah satu cara menghambat korosi adalah dengan menggunakan inhibitor korosi yang dibuat menggunakan bahan-bahan organik. Daun jambu biji (Psidium guajava) mengandung senyawa tanin sebagai penghambat terjadinya korosi. Dalam penelitian ini, kuningan yang digunakan adalah selongsong dari amunisi MU-2TJ kaliber 7,62 mm produksi PT. Pindad pada tahun 1992 dan 1994. Laju korosi dihitung dengan metode pengukuran berat hilang. Preparasi inhibitor ekstrak daun jambu biji dilakukan dengan metode maserasi, daun jambu biji kering 10 gram dilarutkan dalam pelarut air-etanol $100 \mathrm{~mL}$ dengan variasi perbandingan volume air : etanol berturutturut 7:3, 6:4 dan 5:5. Kuningan dengan inhibitor dan tanpa inhibitor direndam selama 15 hari atau 360 jam dalam media larutan $\mathrm{HCl}$ dan $\mathrm{CH}_{3} \mathrm{COOH}$. Hasil menunjukan bahwa dalam media $\mathrm{CH}_{3} \mathrm{COOH}$, effisiensi inhibitor terbesar adalah 42,12\% dengan menggunakan inhibitor ekstrak daun jambu biji dengan perbandingan volume air : etanol 6:4 dalam larutan $\mathrm{CH}_{3} \mathrm{COOH}$ 0,1 M dimana laju korosi kuningan tanpa inhibitor diperoleh $4,34 \times 10^{-6}$ mpy dan laju korosi dengan inhibitor $2,51 \times 10^{-6}$ mpy. Dalam media $\mathrm{HCl}$, efisiensi inhibitor terbesar adalah 7,52 \% dengan menggunakan inhibitor ekstrak daun jambu biji dengan perbandingan 5:5 dalam larutan $\mathrm{HCl}$ 0,05 M, laju korosi kuningan tanpa inhibitor diperoleh $4,81 \times 10^{-6}$ mpy, dan laju korosi dengan inhibitor $4,45 \times 10^{-6}$ mpy.

Kata Kunci-Amunisi, Kuningan, Korosi, Inhibitor, Laju Korosi

\footnotetext{
*Penulis Korespondensi (Andini Dyah Anugrahita)
}

E-mail: andinidyah117@gmail.com 


\section{Pendahuluan}

$\mathrm{K}$ orosi merupakan proses elektrokimia yang diakibatkan karena terjadinya reaksi oksidasi pada logam, namun terjadi reduksi pada oksigen di sekitar logam (udara). Di era society 5.0 saat ini, korosi masih menjadi fenomena yang harus diselesaikan. Korosi dapat terjadi pada setiap logam, termasuk logam kuningan yang menjadi bahan dalam pembuatan selongsong amunisi untuk kepentingan militer. Kinerja amunisi pernah diuji dalam penelitian sebelumnya menggunakan variabel 5 jenis air [1]. Selongsong amunisi atau peluru merupakan salah satu alutsista yang juga perlu mendapatkan perawatan dalam penyimpanannya di dalam gudang penyimpanan guna menghindari kerusakan yang dapat terjadi pada selongsong amunisi. Hal ini dapat disebabkan oleh kondisi penyimpanan amunisi pada gudang senjata dan amunisi memiliki berbagai macam faktor yang dapat menyebabkan korosi pada amunisi dalam penyimpanannya seperti, temperatur pada ruangan, kelembaban, hadirnya asam, dan $\mathrm{CO}_{2}$. Korosi yang terjadi pada suatu logam tidak dapat dihilangkan, namun dapat diatasi atau dicegah dengan berbagai macam cara. Salah satu caranya adalah dengan penambahan inhibitor pada suatu logam [2].

Inhibitor dapat berupa inhibitor organik dan inhibitor anorganik. Inhibitor anorganik cenderung tidak ramah lingkungan dibandingkan dengan inhibitor organik yang lebih memanfaatkan bahan dari alam. Senyawa antioksidan adalah senyawa pemberi elektron. Antioksidan bekerja dengan cara mendonorkan elektronnya kepada senyawa yang bersifat oksidan, sehingga menyebabkan terhambatnya aktivitas dari senyawa oksidan tersebut. Kandungan zat antioksidan seperti polifenol, tanin, alkaloid, saponin, minyak atsiri dan asam amino mempunyai banyak unsur $\mathrm{N}, \mathrm{O}, \mathrm{P}, \mathrm{S}$ yang dapat membentuk senyawa kompleks sulit larut dengan ion logam yang mampu menghambat korosi pada logam [3]. Daun jambu biji merupakan salah satu bahan alami dengan kandungan antioksidan yang dapat dimanfaatkan menjadi inhibitor korosi pada suatu logam. Kandungan kimia yang terdapat dalam jambu biji yaitu buah, daun, dan kulit batang pohon jambu biji mengandung tanin. Kandungan tanin dalam daun jambu biji yang digiling halus diketahui dapat mencapai 17\% [4]

Berdasarkan uraian di atas maka dalam penelitian ini, telah dilakukan analisa pengaruh ekstrak daun jambu biji sebagai inhibitor terhadap laju korosi kuningan selongsong amunisi MU-2TJ kaliber 7,62 mm dalam media korosi larutan $\mathrm{CH}_{3} \mathrm{COOH} \mathrm{0,05} \mathrm{M}$ dan 0,1 $\mathrm{M}$ dan $\mathrm{HCl}$ $0,05 \mathrm{M}$ dan $0,1 \mathrm{M}$.

\section{LANDASAN TEORI}

\section{A. Korosi}

Korosi merupakan reaksi kimia pada bahan-bahan logam menjadi ion pada permukaan logam yang langsung bereaksi lagi dengan lingkungan berair dan oksigen [5]. Proses korosi logam ini berlangsung pada area anoda dan katoda secara secara simultan dan membentuk rangkaian arus listrik tertutup [6].

Dalam Callister dan Rethwisch [7] dijelaskan bahwa tempat terjadinya reaksi oksidasi disebut anoda sehingga reaksi oksidasi dapat disebut juga dengan reaksi anodik. Elektron yang dihasilkan dari masing-masing atom logam yang teroksidasi dan berpindah menjadi bagian dari logam lain yang disebut reaksi reduksi. Misalnya, sebuah logam terkorosi dalam media larutan asam yang memiliki konsentrasi ion hidrogen $\left(\mathrm{H}^{+}\right)$yang tinggi ion hidrogen tereduksi membentuk gas $\mathrm{H}_{2}$ dengan sesuai reaksi :

$$
2 \mathrm{H}^{+}+2 \mathrm{e}^{-} \rightarrow \mathrm{H}_{2}
$$


Secara umum, korosi disebabkan oleh air, namun terdapat beberapa penyebab selain air yang mempengaruhi laju korosi, seperti suhu, kecepatan alir fluida atau kecepatan pengadukan, konsentrasi bahan korosif, dan oksigen [7][8].

Laju korosi merupakan suatu besaran untuk menyatakan kecepatan material bereaksi dengan lingkungannya dalam proses korosi. Menurut Callister [9], salah satu metode penentuan laju korosi adalah metode kehilangan berat (weight loss.) yang didasarkan pada selisih massa awal sebelum pengujian korosi dengan massa akhir setelah pengujian korosi. Laju korosi biasanya dinyatakan dalam mils per year (mpy). Perhitungan laju korosi atas dasar kehilangan massa logam selama pengujian dirumuskan sesuai standar ASTM G1. Persamaan laju korosi dapat ditunjukkan pada persamaan berikut:

$$
\text { Corrosion Rate }(C R)=\frac{K \mathrm{~W}}{\mathrm{pAt}}
$$

dimana :

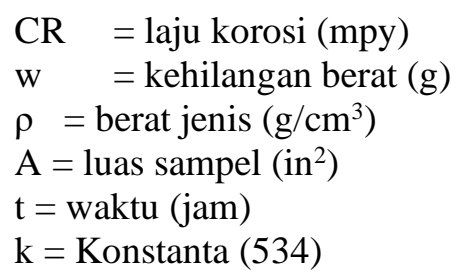

Pengendalian korosi dapat dilakukan dengan beberapa cara antara lain dengan pelapisan. dimana dilakukan dengan memberikan suatu lapisan yang dapat mengurangi kontak antara logam dengan lingkungannya. Lapisan pelindung yang sering dipakai adalah bahan metalik, anoganik ataupuun organik yang relatif tipis serta penambahan inhibitor dimana inhibitor terdiri dari anion atom-ganda yang dapat masuk ke permukaan logam [7].

\section{B. Inhibitor Korosi}

Inhibitor korosi dapat diklasifikasikan menurut bahan pembuatannya, dimana inhibitor terbagi menjadi inhibitor dengan bahan alami dan inhibitor buatan. Inhibitor alami yaitu inhibitor yang terbuat dari bahan organik yang dapat diperbarui. Inhibitor organik merupakan inhibitor yang berasal dari bahan alami yang dapat ditemukan di lingkungan sekitar kita. Inhibitor organik akan menghambat korosi dengan cara teradsorpsi secara kimiawi pada permukaan logam melalui ikatan logam-hetero atom. Contohnya senyawa yang memiliki gugus amina, tio, fosfor, eter dan termasuk senyawa tanin [6].

Inhibitor korosi umumnya digunakan pada konsentrasi yang kecil. Sebuah inhibitor korosi tidak hanya harus mengurangi laju korosi tetapi juga harus kompatibel dengan lingkungannya. Inhibitor korosi dinilai dari efisiensi inhibisinya yang didefinisikan sebagai berikut:

dimana:

$$
I=\frac{C R_{0}-C R_{1}}{C R_{0}} \times 100 \%
$$

I : efisiensi inhibisi

$\mathrm{CR}_{0}$ : laju korosi tanpa inhibitor

$\mathrm{CR}_{1}$ : laju korosi dengan penambahan inhibitor

Beberapa bahan organik yang dapat dijadikan sebagai inhibitor alami karena mengandung senyawa antioksidan, antara lain daun teh, kedelai, dan kopi [4] [10]. 


\section{Daun Jambu Biji.}

Kandungan tanin pada daun jambu biji berkisar 12-18\%, selain itu terdapat kandungan vitamin A. vitamin B1, vitamin C, kalsium, hidrat arang, fosfor, besi, lemak, air dan zat- zat penyamak (psiditanin) [11].

Hal yang menjadi dasar bahwa daun jambu biji dapat dimanfaatkan sebagai inhibitor korosi adalah kandungan tanin yang dimiliki oleh daun jambu biji tersebut. Tanin dapat berfungsi sebagai zat anti korosi karena dalam senyawa tanin, terdapat gugus fungsi hidroksil (-OH) yang melekat pada cincin aromatis sehingga tanin dapat membentuk kompleks khelat dengan kation besi dan logam lainnya [12].

Penelitian yang dilakukan oleh Ubaydillah [13] tentang pengaruh daun jambu biji sebagai inhibitor korosi alami pada rantai dapra kapal diperoleh bahwa konsentrasi optimal laju korosi terjadi pada konsentrasi inhibitor 9\% ekstrak daun jambu biji sebesar 0,066 mpy. Hal tersebut disebabkan karena lapisan yang terbentuk sudah sempurna yang di tandai dengan tertutupnya seluruh permukaan spesimen baja oleh inhibitor.

\section{Logam Kuningan dan Selongsong Amunisi}

Kuningan pada dasarnya adalah paduan tembaga dengan seng sebagai paduan utama. Biasanya kandungan seng yang terkandung mencapai 40\% [14]. Unsur tembaga ( $\mathrm{Cu})$ merupakan komponen utama dari kuningan sehingga sering diklasifikasikan sebagai paduan tembaga. Jumlah kadar seng ( $\mathrm{Zn})$ mempengaruhi warna kuningan yang bervariasi dari coklat kemerahan gelap hingga ke cahaya kuning keperakan [15]. Selongsong amunisi terbuat dari kuningan yang mengandung $30 \%$ seng dan $70 \%$ tembaga. Kuningan merupakan material yang mempunyai sifat tahan korosi yang baik, namun sensitif pada beberapa media seperti asam nitrat dan asam asetat [16].

\section{Metode Penelitian}

\section{A. Alat dan Bahan}

Adapun alat yang digunakan dalam penelitian ini antara lain timbangan analitik digital, beaker glass, kertas saring, gergaji besi, sarung tangan, mortar, pipet tetes, dan oven. Bahan yang digunakan antara lain selongsong amunisi MU 2-TJ kaliber 7,62 mm lot number 1992 dan 1994, daun jambu biji, larutan $\mathrm{HCl} 0,05 \mathrm{M}$ dan 0,1 M, larutan $\mathrm{CH}_{3} \mathrm{COOH}$ 0,05 $\mathrm{M}$ dan 0,1 M, Aquadest dan etanol.

\section{B. Pembuatan Spesimen}

Spesimen pada penelitian ini adalah kuningan dari selongsong amunisi kaliber 7,62 mm. Primer pada selongsong kuningan diledakan, kemudian dipotong sedemikian hingga menjadi segiempat. Selanjutnya dicuci dengan sabun dan diamplas untuk menghilangkan pengotornya yang dapat mempengaruhi penimbangan.

\section{Pembuatan Inhibitor Ekstrak Daun Jambu Biji}

Daun jambu biji dicuci dan dikeringkan menggunakan microwave dengan suhu $50-60{ }^{\circ} \mathrm{C}$ selama 3 menit. kemudian daun jambu biji di blender sampai halus. 10 gram daun jambu biji yang telah dihaluskan kemudian dicampur dengan etanol dan aquades dengan perbandingan volume etanol : aquades berturut-turut 7:3 (70\% aquades dan 30\% etanol), 6:4 (60\% aquades dan 40\% etanol), dan 5:5 (50\% aquades dan 50\% etanol) dalam gelas kimia $100 \mathrm{~mL}$. Diamkan 
selama 1 hari Ekstrak yang sudah jadi kemudian disaring menggunakan kertas saring. Ekstrak yang sudah disaring yang kemudian digunakan sebagai inhibitor alami.

\section{Pemberian Inhibitor Pada Logam Kuningan dan Penentuan Weight Loss} hari.

Logam kuningan diinhibisi direndam pada ekstrak daun jambu biji dan diamkan selama 2

Untuk menentukan Weight Loss, ditimbang berat awal spesimen kuningan, kemudian satu per satu spesimen yang tersebut direndam dalam larutan $\mathrm{HCl} \mathrm{0,05} \mathrm{M}$ dan 0,1 $\mathrm{M}$ dan larutan $\mathrm{CH}_{3} \mathrm{COOH}$ 0,05 M dan 0,1 M lalu didiamkan selama 15 hari atau 360 jam. Setelah itu ditimbang kembali sebagai berat akhir logam.

\section{HASIL DAN ANALISIS}

\section{A. Data Awal Spesimen}

Dalam penelitian ini, logam kuningan selongsong amunisi MU 2-TJ kaliber 7,62 mm lot number atau tahun produksi 1992 dan 1994. Pada Tabel I, ditampilkan data awal spesimen logam kuningan dari selongsong amunisi MU-2TJ lot number 1992 dan lot number 1994 berdasarkan media korosi larutan $\mathrm{CH}_{3} \mathrm{COOH}$ dan $\mathrm{HCl}$ yang digunakan untuk pengujian korosi masing-masing spesimen. Data ini selanjutnya digunakan pada perhitungan laju korosi tanpa inhibitor dan laju dengan adanya inhibitor ekstrak daun jambu biji.

TABEL I

DATA AWAL DiMENSI DAN BERAT SPESIMEN

\begin{tabular}{|c|c|c|c|c|}
\hline Media & $\begin{array}{l}\text { Lot Number } \\
\text { Selongsong }\end{array}$ & $\begin{array}{c}\text { Rasio Pelarut } \\
\text { Inhibitor } \\
\text { (Air : Etanol) }\end{array}$ & $\begin{array}{l}\text { Berat awal } \\
\quad \text { (gram) }\end{array}$ & $\begin{array}{c}\text { Luas } \\
\text { Permukaan } \\
\left(\text { inch }^{2}\right) \\
\end{array}$ \\
\hline \multirow[t]{8}{*}{$\mathrm{CH}_{3} \mathrm{COOH} 0,05 \mathrm{M}$} & Lot 92 & Tanpa inhibitor & 7,5017 & 2,0612 \\
\hline & & $6: 4$ & 7,6580 & 2,1007 \\
\hline & & $5: 5$ & 6,6270 & 1,8402 \\
\hline & & $7: 3$ & 6,5907 & 1,8310 \\
\hline & Lot 94 & Tanpa inhibitor & 7,3332 & 2,0186 \\
\hline & & $6: 4$ & 7,2457 & 1,9965 \\
\hline & & $5: 5$ & 7,2088 & 1,9872 \\
\hline & & $7: 3$ & 7,6327 & 2,0943 \\
\hline \multirow[t]{8}{*}{$\mathrm{HCl} 0,05 \mathrm{M}$} & Lot 92 & Tanpa inhibitor & 7,4047 & 2,0367 \\
\hline & & $6: 4$ & 7,2182 & 1,9895 \\
\hline & & $5: 5$ & 7,6696 & 2,1036 \\
\hline & & $7: 3$ & 7,8069 & 2,1383 \\
\hline & Lot 94 & Tanpa inhibitor & 7,1071 & 1,9615 \\
\hline & & $6: 4$ & 7,3509 & 2,0231 \\
\hline & & $5: 5$ & 7,7381 & 2,1209 \\
\hline & & $7: 3$ & 7,2334 & 1,9934 \\
\hline
\end{tabular}


Lanjutan Tabel 1.

\begin{tabular}{|c|c|c|c|c|}
\hline Media & $\begin{array}{l}\text { Lot Number } \\
\text { Selongsong }\end{array}$ & $\begin{array}{c}\text { Rasio Pelarut } \\
\text { Inhibitor } \\
\text { (Air : Etanol) } \\
\end{array}$ & $\begin{array}{l}\text { Berat awal } \\
\quad \text { (gram) }\end{array}$ & $\begin{array}{c}\text { Luas } \\
\text { Permukaan } \\
\left(\text { inch }^{2}\right) \\
\end{array}$ \\
\hline \multirow[t]{8}{*}{$\mathrm{CH}_{3} \mathrm{COOH} 0,1 \mathrm{M}$} & \multirow[t]{4}{*}{ Lot 92} & Tanpa inhibitor & 6,6359 & 1,8425 \\
\hline & & $6: 4$ & 6,8625 & 1,8998 \\
\hline & & $5: 5$ & 6,9195 & 1,9142 \\
\hline & & $7: 3$ & 6,6848 & 1,8549 \\
\hline & \multirow[t]{4}{*}{ Lot 94} & Tanpa inhibitor & 7,2809 & 2,0055 \\
\hline & & $6: 4$ & 7,271 & 2,0030 \\
\hline & & $5: 5$ & 7,0979 & 1,9593 \\
\hline & & $7: 3$ & 6,9262 & 1,9159 \\
\hline \multirow[t]{8}{*}{$\mathrm{HCl} \mathrm{0,1 \textrm {M }}$} & \multirow[t]{4}{*}{ Lot 92} & Tanpa inhibitor & 7,0502 & 1,9472 \\
\hline & & $6: 4$ & 7,1990 & 1,9848 \\
\hline & & $5: 5$ & 6,9195 & 1,9142 \\
\hline & & $7: 3$ & 6,9944 & 1,9331 \\
\hline & \multirow[t]{4}{*}{ Lot 94} & Tanpa inhibitor & 6,8906 & 1,9069 \\
\hline & & $6: 4$ & 6,9949 & 1,9332 \\
\hline & & $5: 5$ & 7,4854 & 2,0572 \\
\hline & & $7: 3$ & 7,2160 & 1,9891 \\
\hline
\end{tabular}

Laju korosi kemudian ditentukan dengan menggunakan metode weight loss, sehingga untuk menghitung laju korosi yang terjadi pada logam kuningan selongsong amunisi MU-2TJ, diperlukan data-data berat awal, berat akhir, massa jenis benda, luas permukaan benda, waktu kontak antara logam dan media. Perhitungan laju korosi yang menggunakan metode weight loss digunakan persamaan (1).

Setelah diperoleh laju korosi diketahui tiap-tiap spesimen maka data laju korosi tersebut digunakan untuk menghitung efisiensi dari inhibitor ekstrak daun jambu biji dengan menggunakan persamaan (2). Hasil efisiensi inhibitor ini menggambarkan persentase seberapa besar inhibitor bekerja untuk mengahambat laju korosi logam kuningan amunisi MU-2TJ.

\section{B. Analisis Data}

Spesimen yang telah disiapkan direndam pada lingkungan berupa larutan yang telah di siapkan dalam 16 tempat yang berbeda yang dibagi menjadi 2. Pada 8 spesimen yang pertama direndam pada media korosi larutan asam dengan konsentrasi 0,05 M. Pada 8 spesimen yang kedua direndam pada media larutan asam dengan konsentrasi $0,1 \mathrm{M}$. Perendaman dilakukan dalam jangka waktu yang sama yaitu 15 hari (360 jam). Setelah diperoleh data akhir spesimen, perhitungan laju korosi dapat dilakukan pada tiap-tiap spesimen. Berikut ini adalah pembahasan tentang pengaruh inhibitor terhadap laju korosi logam kuningan amunisi kaliber kecil MU-2TJ lot number 1992 dan 1994. 


\section{1) Pengaruh ratio pelarut inhibitor terhadap korosi dalam media $\mathrm{CH}_{3} \mathrm{COOH}$}

Pada penelitian ini, larutan yang digunakan untuk media uji korosi selongsong amunisi MU-2TJ adalah $\mathrm{CH}_{3} \mathrm{COOH}$ (asam asetat) dengan konsentrasi $0,05 \mathrm{M}$ dan $0,1 \mathrm{M}$, sedangkan variasi ratio pelarut air:etanol adalah 0 (tanpa inhibitor), 6:4, 5:5, dan 7:3. Tabel II menampilkan hasil penimbangan berat akhir spesimen logam kuningan selongsong amunisi setelaselama 15 hari (360 jam) dalam larutan $\mathrm{CH}_{3} \mathrm{COOH}$ masing-masing 0,05 M.

TABEL II

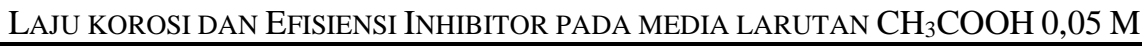

\begin{tabular}{|c|c|c|c|c|c|}
\hline \hline $\begin{array}{c}\text { Lot Number } \\
\text { Spesimen }\end{array}$ & $\begin{array}{c}\text { Rasio Pelarut } \\
\text { Inhibitor } \\
\text { (Air : Etanol) }\end{array}$ & $\begin{array}{c}\mathrm{W} \\
\text { (gram) }\end{array}$ & $\begin{array}{c}\mathrm{A} \\
\left(\mathrm{in}^{2}\right)\end{array}$ & $\begin{array}{c}\text { Laju Korosi } \\
(\mathrm{x} \mathrm{10} \text { }\end{array}$ & $\begin{array}{c}\text { Efisiensi } \\
\text { Inhibitor (\%) }\end{array}$ \\
\hline Lot 92 & Tanpa inhibitor & 0,0498 & 2,0612 & 0,004266518 & 0 \\
& $6: 4$ & 0,0400 & 2,1007 & 0,003362492 & 21,1888 \\
& $5: 5$ & 0,0431 & 1,8402 & 0,004136024 & 3,0586 \\
& $7: 3$ & 0,0401 & 1,8310 & 0,003867411 & 9,3544 \\
& Tanpa inhibitor 94 & 0,0504 & 2,0186 & 0,004408998 & 0 \\
& $6: 4$ & 0,0475 & 1,9965 & 0,004201323 & 4,7102 \\
& $5: 5$ & 0,0494 & 1,9872 & 0,004389878 & 0,4337 \\
& $7: 3$ & 0,0521 & 2,0943 & 0,004393015 & 0,3625 \\
\hline \hline
\end{tabular}

Dari Tabel II, diperoleh hasil pengujian laju korosi dalam media larutan $\mathrm{CH}_{3} \mathrm{COOH} 0,05$ M, bahwa hasil optimal inhibitor adalah berat 10 gram daun jambu biji kering dan ratio volume pelarut inhibitor (air:etanol) 6:4 yaitu campuran dari 60\% aquades dan $40 \%$ etanol. Dengan ratio volume pelarut (air:etanol) inhibitor ekstrak daun jambu biji 6:4, laju korosi pada selongsong lot number 1992 dapat dihambat dari $0,004266518 \times 10^{-3}$ mpy menjadi $0,003362492 \times 10^{-3}$ mpy atau efisiensi sebesar $21,1888 \%$.

TABEL III

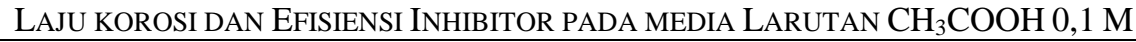

\begin{tabular}{|l|c|c|c|c|c|}
\hline $\begin{array}{c}\text { Lot number } \\
\text { Spesimen }\end{array}$ & $\begin{array}{c}\text { Rasio Pelarut } \\
\text { Inhibitor } \\
\text { (Air : Etanol) }\end{array}$ & $\begin{array}{c}\mathrm{W} \\
\text { (gram) }\end{array}$ & $\begin{array}{c}\mathrm{A} \\
\left(\mathrm{in}^{2}\right)\end{array}$ & $\begin{array}{c}\text { Laju Korosi } \\
(\mathrm{x} \mathrm{10} \text { mpy) }\end{array}$ & $\begin{array}{c}\text { Efisiensi } \\
\text { Inhibitor (\%) }\end{array}$ \\
\hline Lot 92 & Tanpa inhibitor & 0,0384 & 1,8425 & 0,00368023 & 0 \\
& $6: 4$ & 0,0335 & 1,8998 & 0,00311386 & 15,3896 \\
& $5: 5$ & 0,0329 & 1,9142 & 0,00303508 & 17,5302 \\
& $7: 3$ & 0,0386 & 1,8549 & 0,00367476 & 0,1487 \\
\hline Lot 94 & 0,0493 & 2,0055 & 0,00434093 & 0 \\
& $6: 4$ & 0,0285 & 2,0030 & 0,00251259 & 42,1185 \\
& $5: 5$ & 0,0433 & 1,9593 & 0,00390260 & 10,0976 \\
& $7: 3$ & 0,0406 & 1,9159 & 0,00374211 & 13,7947 \\
\hline \hline
\end{tabular}

Dari Tabel III diperoleh hasil pengujian laju korosi dalam media larutan $\mathrm{CH}_{3} \mathrm{COOH} 0,1$ $\mathrm{M}$, bahwa hasil optimal inhibitor adalah berat 10 gram daun jambu biji kering dan ratio volume pelarut inhibitor (air:etanol) 6:4 yaitu campuran dari 60\% aquades dan $40 \%$ etanol. Dengan ratio volume pelarut (air:etanol) inhibitor 6:4, laju korosi pada selongsong lot 
number 1994 dapat dihambat dari $0,00434093 \times 10^{-3}$ mpy menjadi $0,00251259 \times 10^{-3}$ mpy atau efisiensi sebesar $42,1185 \%$.

\section{2) Pengaruh konsentrasi inhibitor terhadap korosi dalam media $\mathrm{HCl}$.}

Pada penelitian ini, $\mathrm{HCl}$ yang digunakan untuk media uji korosi pada selongsong amunisi kaliber 7,62 (MU-2TJ) dengan konsentrasi $0,05 \mathrm{M}$ dan 0,1 $\mathrm{M}$, sedangkan variasi rasio pelarut inhibitor (air:etanol) adalah 0, 6:4, 5:5, dan 7:3. Tabel IV menampilkan tabel hasil perhitungan laju korosi dan efisiensi inhibitor logam kuningan selongsong amunisi MU 2-TJ selama 15 hari (360 jam) dalam larutan $\mathrm{HCl} 0,05 \mathrm{M}$.

TABEL IV

LAJU KOROSI DAN EFISIENSI INHIBITOR PADA MEDIA LARUTAN HCL 0,05 M

\begin{tabular}{|c|c|c|c|c|c|}
\hline $\begin{array}{c}\text { Lot number } \\
\text { Spesimen }\end{array}$ & $\begin{array}{c}\text { Rasio Pelarut } \\
\text { Inhibitor } \\
\text { (Air : Etanol) }\end{array}$ & $\begin{array}{c}\mathrm{W} \\
(\mathrm{gram})\end{array}$ & $\mathrm{A}\left(\mathrm{in}^{2}\right)$ & $\begin{array}{c}\text { Laju Korosi } \\
\left(\mathrm{x} \mathrm{10} 0^{-3} \mathrm{mpy}\right)\end{array}$ & $\begin{array}{c}\text { Efisiensi } \\
\text { Inhibitor (\%) }\end{array}$ \\
\hline Lot 92 & Tanpa Inhibitor & 0,0448 & 2,0320 & 0,003893185 & 0 \\
& $6: 4$ & 0,0437 & 1,9829 & 0,003891629 & 0,0400 \\
& $5: 5$ & 0,0441 & 2,1018 & 0,003705188 & 4,8289 \\
& $7: 3$ & 0,0464 & 2,1379 & 0,003832515 & 1,5584 \\
\hline \multirow{2}{*}{ Lot 94} & Tanpa Inhibitor & 0,0534 & 1,9615 & 0,004807505 & 0 \\
& $6: 4$ & 0,0514 & 2,0231 & 0,004486537 & 6,6764 \\
& $5: 5$ & 0,0534 & 2,1209 & 0,004446088 & 7,5178 \\
& $7: 3$ & 0,0542 & 1,9934 & 0,004801406 & 0,1269 \\
\hline
\end{tabular}

Dari Tabel IV diperoleh bahwa hasil optimal inhibitor adalah berat 10 gram daun jambu biji kering dan ratio volume pelarut inhibitor (air : etanol) adalah 5:5 yaitu campuran dari $50 \%$ aquades dan 50\% etanol. Dengan ratio volume pelarut (air : etanol) inhibitor 5:5, laju korosi pada selongsong lot number 1994 dapat dihambat dari 0,004807505 x $10^{-3}$ mpy menjadi $0,004446088 \times 10^{-3} \mathrm{mpy}$ atau efisiensi sebesar 7,5178\%.

TABEL V

LAJU KOROSI DAN EFISIENSI INHIBITOR PADA MEDIA LARUTAN HCL 0,1 M

\begin{tabular}{|c|c|c|c|c|c|}
\hline \hline $\begin{array}{c}\text { Lot number } \\
\text { Spesimen }\end{array}$ & $\begin{array}{c}\text { Rasio Pelarut } \\
\text { Inhibitor } \\
\text { (Air : Etanol) }\end{array}$ & $\begin{array}{c}\text { selisih } \\
\text { (gram) }\end{array}$ & $\begin{array}{c}\text { A } \\
\text { (in2) }\end{array}$ & $\begin{array}{c}\text { Laju Korosi } \\
\text { (x 10-3 mpy) }\end{array}$ & $\begin{array}{c}\text { Efisiensi } \\
\text { Inhibitor (\%) }\end{array}$ \\
\hline Lot 92 & Tanpa Inhibitor & 0,0384 & 1,8425 & 0,002575514 & 0 \\
& $6: 4$ & 0,0335 & 1,8998 & 0,002580109 & $-0,1784$ \\
& $5: 5$ & 0,0329 & 1,9142 & 0,002583047 & $-0,2925$ \\
& $7: 3$ & 0,0386 & 1,8549 & 0,002576029 & $-0,0200$ \\
\hline Lot 94 & Tanpa Inhibitor & 0,0493 & 2,0055 & 0,001472419 & 0 \\
& $6: 4$ & 0,0285 & 2,0030 & 0,001479750 & $-0,4979$ \\
& $5: 5$ & 0,0433 & 1,9593 & 0,001485025 & $-0,8562$ \\
& $7: 3$ & 0,0406 & 1,9159 & 0,001473700 & $-0,0871$ \\
\hline \hline
\end{tabular}

Dari Tabel $\mathrm{V}$ diperoleh hasil pengujian laju korosi dalam media larutan $\mathrm{HCl} 0,1 \mathrm{M}$, inhibitor ekstrak daun jambu biji tidak bekerja menghambat laju korosi yang terjadi terhadap logam kuningan. Hal ini disebabkan karena tingginya konsentrasi $\mathrm{HCl}$ sebagai media korosi 
yang dibuktikan bahwa pada data tabel IV, inhibitor ekstrak daun jambu biji masih dapat bekerja menghambat laju korosi dalam media larutan $\mathrm{HCl}$ yang lebih encer.

\section{3) Pengaruh kekuatan dan konsentrasi asam terhadap laju korosi.}

Dengan variasi rasio pelarut inhibitor (Air:Etanol) yang optimal dapat diketahui pengaruh kekuatan dan konsentrasi asam terhadap laju korosi. Tabel VI menampilkan perbandingan laju korosi akibat kekuatan dan konsentrasi asam.

TABEL V

Pengaruh Media Asam terhadap Laju Korosi

\begin{tabular}{|l|c|c|c|}
\hline Jenis Asam dan Konsentrasi & $\begin{array}{c}\text { Rasio Pelarut } \\
\text { Inhibitor } \\
\text { (Air : Etanol) }\end{array}$ & $\begin{array}{c}\text { Laju Korosi } \\
\text { (x 10-3 mpy) }\end{array}$ & $\begin{array}{c}\text { Efisiensi } \\
\text { Inhibitor (\%) }\end{array}$ \\
\hline Larutan $\mathrm{CH}_{3} \mathrm{COOH} 0,05 \mathrm{M}$ & $6: 4$ & 0,003362492 & 21,1888 \\
Larutan $\mathrm{HCl} 0,05 \mathrm{M}$ & $5: 5$ & 0,0044460088 & 7,5178 \\
Larutan $\mathrm{CH}_{3} \mathrm{COOH} 0,1 \mathrm{M}$ & $6: 4$ & 0,00251259 & 42,1185 \\
Larutan $\mathrm{HCl} \mathrm{0,1} \mathrm{M}$ & $7: 3$ & 0,002576029 & $-0,0200$ \\
\hline
\end{tabular}

\section{KESIMPULAN}

Dalam media korosi $\mathrm{CH}_{3} \mathrm{COOH}$, effisiensi inhibitor terbesar adalah $42,12 \%$ dengan menggunakan inhibitor ekstrak daun jambu biji dengan perbandingan volume air : etanol 6:4 dalam larutan $\mathrm{CH}_{3} \mathrm{COOH} 0,1 \mathrm{M}$ dimana laju korosi kuningan selongsong amunisi $\mathrm{MU}$ 2-TJ tanpa inhibitor diperoleh 4,34 x $10^{-6}$ mpy dan laju korosi dengan inhibitor $2,51 \times 10^{-6} \mathrm{mpy}$. Dalam media $\mathrm{HCl}$, effisiensi inhibitor terbesar adalah 7,52\% dengan menggunakan inhibitor ekstrak daun jambu biji dengan perbandingan volume air : etanol 5:5 dalam larutan $\mathrm{HCl}$ 0,05 M dimana laju korosi kuningan selongsong amunisi MU 2-TJ tanpa inhibitor diperoleh 4,81 x 10 mpy dan laju korosi dengan inhibitor 4,45 x $10^{-6} \mathrm{mpy}$.

Disarankan agar dilakukan penelitian lebih lanjut dengan mempelajari morfologi permukaan kuningan akibat korosi.

\section{UCAPAN TERIMA KASIH}

Penulis mengucapkan terima kasih yang setinggi-tingginya kepada Gubernur AAU dan Kepala Departemen Aeronautika AAU atas ijin melaksanakan penelitian menggunakan amunisi yang tersimpan di Gudang Senjata AAU dan fasilitas penelitian. Demikian pula ucapan terima kasih kepada semua pihak atas terbitnya naskah ini pada Seminar Nasional Sains Teknologi dan Inovasi Indonesia 2021 Akademi Angkatan Udara.

\section{REFERENSI}

[1] A. Nugraha and A. Infantono, "Analisis Kualitas Peluru Berdasarkan Variabel 5 Jenis Air Menggunakan Metode Uji Kadar Air dan Uji Tembak”, AAU-JDST, vol. 6, no. 1, pp. 1-16, Dec. 2020.

[2] H., X. Salahudin, N. Mulyaningsih, "Analisa Penambahan Inhibitor Ekstrak Daun Teh Pada Pengait Crane Terhadap Laju Korosi,” Jurnal MER-C No. 2/Vol. 1, e-ISSN : 2622-5735, 2018 
[3] Asdim, "Penentuan Efisiensi Inhibisi Ekstrak Kulit Buah Manggis (Garcinia mangostana L.) pada Reaksi Korosi Baja dalam Larutan Asam,” Jurnal Gradien Vol.3 No.2, pp. 273-276, 2007.

[4] Fachry, A Rasyid, RM. A. Sastrawan, and G. Svingkoe, "Kondisi Optimal Proses Ekstraksi Tanin dari Daun Jambu Biji Menggunakan Pelarut Etanol," Prosiding STNK TOPI (7), 2012, pp. 69-73.

[5] K.R. Thretewey, J. Chamberlain, "Corrosion for Science and Engineering 2nd Ed, "London: Longman, 1995.

[6] Haryono, Gogot, and B. Sugiarto, "Ekstrak Bahan Alam sebagai Inhibitor Korosi," Yogyakarta: Jurusan Teknik Kimia FTI UPN Veteran, 2010.

[7] S. Djaprie, "Ilmu dan Teknologi Bahan ed. 5," Jakarta : Penerbit. Erlangga, 1995.

[8] Kirk and Othmer, "Encyclopedia of Chemical Technology 2nd ed.", New York : John Willey and Sons, 1965.

[9] W. D., Callister Jr. and D.G. Rethwisch, "Materials Scienceand Engineering : An Introduction, 9th Edition," Hoboken : John Wiley \&Sons, Inc., 2013

[10] Habibie, A. Lubis and A.E. Palupi, "Pengaruh Daun Teh dan Daun Jambu Biji sebagai Inhibitor Organik Alami pada Baja SS 304 dalam Larutan Asam,” Jurnal Teknik Mesin (JTM) 03 Nomor 01, 2014, pp. 9-13,

[11] A. Jiménez-Escrig, M. Rincón, R. Pulido, and F. Saura-Calixto, "Guava Fruit (Psidium guajava L.) as a New Source of Antioxidant Dietary Fiber," Journal of Agricultural and Food Chemistry 49 (11), 2001. pp. 54895493.

[12] F. Ali, D. Saputri, and R. F. Nugroho, , "Pengaruh Waktu Perendaman dan Konsentrasi Ekstrak Daun Jambu Biji (Psidium Guajava, Linn) Sebagai Inhibitor Terhadap Laju Korosi Baja SS 304 Dalam Larutan Garam dan Asam,” Jurnal Teknik Kimia No.1, Vol 20, 2014, pp. 28-37.

[13] G. Ubaydillah, N. Mulyaningsih, and C., "Pengaruh Penambahan Inhibitor Ekstrak Daun Jambu Biji Terhadap Laju Korosi Pada Rantai Dapra Kapal," Jurnal MER-C No. 1/Vol.2, 2019.

[14] T. Surdia, and K. Chijiiwa, “Teknologi Pengecoran Logam,” Jakarta Timur: Penerbit Balai Pustaka, 1987.

[15] I. Cahyono, "Analisis Hasil Pengecoran Kuningan (CuZn) Dengan Variasi Media Pendinginan (Air Sumur, Oli SAE 40 dan Udara) Menggunakan Cetakan Pasir CO,", Skripsi, Universitas Muhammadiyah Surakarta 2018

[16] E.J. Rahayu, "Pengaruh Komposisi Kuningan (CuZn) Terhadap Kekuatan Impact, Kekerasan Dan Struktur Mikro Hasil Pengecoran Aluminium (Al) dengan Menggunakan Tungku Listrik," Skripsi, Universitas Negeri Semarang, Semarang, 2018.

[17] M.G. Fontana, “Corrosion Engineering. Third edition,” Singapore : McGraw-Hill Company, 1987. 